(Venice: Giolito, 1542; Valgrisi, 1556; and Franceschi, 1584), and how the illustrators chose to either isolate or put together the episodes of the relevant canto. In addition to other paintings, Rivoletti dwells on the plates that Jean Honoré Fragonard (1732-1806) dedicated to Orlando furioso in an attempt to immortalize both Ariosto as narrator and the limited perspective of the characters in various scenes.

In the last pages, detailed bibliographical appendices complete the volume, including all essays mentioned in the book.

Through a very detailed, interdisciplinary, and updated analysis of Ariosto's masterpiece, Rivoletti delineates the phases of the history of a peculiar kind of irony that lived in a Renaissance poem and later, both in its critics and in another vital literary genre. Although not immediately understood in its whole refined complexity, the Orlando furioso does not cease to speak to its readers and to exhibit its extraordinary modernity.

JOHNNY L. BERTOLIO

University of Toronto

\title{
Roudaut, François.
}

Sur le sonnet 31 des Regrets. Éléments d'histoire des idées à la Renaissance. Paris: Classiques Garnier, 2014. Pp. 272. ISBN 978-2-8124-3251-4 (paperback) $€ 29$.

François Roudaut's monograph Sur le sonnet 31 des Regrets. Éléments d'histoire des idées à la Renaissance provides a detailed structural reading of Les Regrets' famous sonnet and places the poem in conversation with contemporary and classical sources. This second component takes up the bulk of the work; with the help of relevant intertexts, Roudaut traces the genealogy of the sonnet's words and suggests various frameworks for their interpretation. It is through this rich web of terms and ideas that Roudaut gives us a glimpse of how the poem might have been read at the time of its publication.

As Roudaut explains, Du Bellay composed Les Regrets during his stay in Rome where he served as steward for the cardinal Jean Du Bellay, but he only published the collection together with a series of other works upon his return to France in 1558. The sonnet central to Roudaut's study explicitly 
thematizes Du Bellay's geographical situation at the time of composition: it is a lament of his (self-inflicted) exile in Rome and an expression of his longing for his hometown in France. Together with this historical setting, Roudaut also sketches a brief overview of Les Regrets as a whole and of sonnet 31's immediate context-a group of poems that focus on travel and deplore the miseries of exile. Sonnet 31, however, is noteworthy for the skill with which it articulates this theme. Roudaut shows its careful manipulation of the constraining forms of the sonnet and, throughout the book, returns to its significant structural features. He highlights, for instance, how certain rhyme endings surface again and again across Les Regrets and create a network of echoes that lends depth to individual poems. Thus, for example, the rhyme endings "Latin" and "Palatin" of sonnet 31 already occur in sonnet 10, yet in opposite order. According to Roudaut, this repetition with a difference is highly characteristic of Du Bellay's poetic style and symptomatic of his condition as an exile: despite the semblance of change he is perpetually caught in a cycle of repetition.

As in this example, technical comments almost always accompany and strengthen Roudaut's broader discussions of lexical history and philosophical tradition. In a linear reading of the poem, Roudaut pauses at nearly every word in order to examine its contemporary resonances and its historical precedents. His commentary starts with the very first word of the poem, "heureux" (happy), and proceeds with constant care and attention to detail in order to provide the same type of analysis for the remaining words of the poem. At times, this word-by-word analysis opens up to include discussions of key concepts hidden behind a given word. The analysis of "heureux", for instance, leads to a general reflection on the significance of "happiness" in classical sources and in contemporary Renaissance texts. Similarly, the mention of "palais Romains" (Roman palaces) triggers a reflection on the significance of Rome in the sixteenth century as a city claimed both by pagan antiquity and contemporary Christianity. In this way, Roudaut's work delivers on its title and provides "des éléments d'histoire des idées à la Renaissance" (elements of a history of ideas in the Renaissance): the words of the poem become gateways for an exploration of the multiple and interacting valences of the ideas that inform the French Renaissance.

In order to adequately explain these ideas and trace their history, classical and early Christian texts are crucial for Roudaut. Throughout the volume, Roudaut cites those texts and authors whom he believes directly influenced 
Du Bellay-above all the Roman poets and prose writers Cicero, Horace, Virgil, Ovid, and Seneca as well as the Homeric epics. Although Roudaut only intermittently (often in lengthy footnotes) provides evidence for how $\mathrm{Du}$ Bellay may have accessed and read these texts (in the case of Homer it would be interesting to know, for instance, whether Du Bellay read the original in ancient Greek or in a Latin translation), the comparison with such authors is illuminating and shows how Du Bellay's exile in Rome is also a literary exile. Du Bellay, as Roudaut's work suggests, can only articulate his distance from France through a literary tradition from which he is already separated by centuries. In order to explain and deepen our understanding of this existential and literary predicament, Roudaut draws on a number of platonic and Neoplatonic authors. Often, it is the Neoplatonists Plotinus and Augustine that Roudaut turns to in order to explain a self-here, Du Bellay-that has been displaced from its "essence" or "centre" and that suffers from this remove without any hope of reprieve.

And yet, this practice that moves seamlessly between the study of sources and the discussion of intellectual frameworks can at times be confusing. For example, the status of Augustine's or Plotinus's writings-whether they represent historical intertexts of Du Bellay's sonnet or merely interpretive aids for the modern reader-is not always made explicit. Such uncertainty, however, may be part of Roudaut's intention. The blurred boundaries certainly achieve the effect of recreating an intellectual environment in which ancient and Renaissance texts inform the reading process and produce a host of free associations. The slow and careful reading this book demands thus forces us to confront the complexities not only of Du Bellay's sonnet but also of a period whose vibrancy would be diminished by any simple analysis.

VANESSA GLAUSER

Stanford University 